Volume 8 | Issue 2

2-11-2021

\title{
Is the Word "Consumer" Biasing Trademark Law?
}

Dustin Marlan

University of Massachusetts Dartmouth School of Law, dmarlan@umassd.edu

Follow this and additional works at: https://scholarship.law.tamu.edu/lawreview

Part of the Consumer Protection Law Commons, and the Intellectual Property Law Commons

\section{Recommended Citation}

Dustin Marlan, Is the Word "Consumer" Biasing Trademark Law?, 8 Tex. A\&M L. Rev. 367 (2021).

Available at: https://doi.org/10.37419/LR.V8.I2.4

This Article is brought to you for free and open access by Texas A\&M Law Scholarship. It has been accepted for inclusion in Texas A\&M Law Review by an authorized editor of Texas A\&M Law Scholarship. For more information, please contact aretteen@law.tamu.edu. 


\title{
IS THE WORD "CONSUMER" BIASING TRADEMARK LAW?
}

\author{
by: Dustin Marlan*
}

\begin{abstract}
Our trademark law uses the term "consumer" constantly, reflexively, and unconsciously to label the subject of its purpose - the purchasing public. According to the U.S. Supreme Court, trademark law has "a specialized mission: to help consumers identify goods and services they wish to purchase, as well as those they want to avoid." As one leading commentator puts it, "trademarks are a property of consumers' minds," and "the consumer, we are led to believe, is the measure of all things in trademark law."

Much criticism has been rightly levied against trademark law's treatment of the consumer as passive, ignorant, and gullible. For instance, consumers are seen as requiring protection from any and all marketplace confusion and have no standing to sue under the Lanham Act. However, that a contributing factor to such treatment could be the linguistic bias stemming from the law's label of the buying public as mere consumers - rather than, for instance, "citizens," "persons," "individuals," or "humans"-has not, until now, been directly addressed.

This Article urges those involved in trademark and advertising law-e.g., judges, lawyers, lawmakers, and scholars - to rethink our ubiquitous use of the derogatory consumer label. To this end, the Article first explores "consumer" as a dehumanizing, anti-ecological, and nonsensical metaphor for "one that utilizes economic goods." It then examines social psychology experiments finding that use of "consumer" has potentially deleterious effects for society given the negative stereotypes that it engenders as a social categorization. The Article claims, by extension, that the implicit linguistic bias inherent in consumer rhetoric might contribute to trademark law defining the public in a manner that is patronizing, biased, insulting, and indulgent of likelihood-ofconfusion claims. The Article suggests that we either work to phase out the "consumer" label and replace it with more appropriate terminology (e.g., "citizen”), or at least pause to acknowledge the word's potentially biasing effects.
\end{abstract}

DOI: https://doi.org/10.37419/LR.V8.I2.4

* Assistant Professor of Law, University of Massachusetts School of Law. Many thanks to Quinn Burns, Michael Carroll, Margaret Chon, Margaret Drew, Justine Dunlap, Christine Farley, Rebecca Flanagan, Brian Frye, Michael Grynberg, Jeremiah Ho, Jessica Kiser, Yvette Joy Liebesman, Liz McCuskey, Janewa Osei-Tutu, Danya Reda, Alexandra Roberts, Zvi Rosen, Matthew Sipe, Madhavi Sunder, John Rice, Shaun Spencer, Kim Vu-Dinh, John Yoon, and participants at the Medicine, Music, and Mascots: Furthering Social Justice in the Age of Intellectual Property conference at Gonzaga University School of Law and the 8th Annual Trademark Works-in-Progress Colloquium at American University Washington College of Law for helpful comments and suggestions. All remaining biases-implicit and linguistic_are my own. 
TABLE OF CONTENTS

I. IntRoduction.................................... 368

II. The Consumer Metaphor ...................... 374

A. Consumer as Dehumanizing ................... 377

B. Consumer as Wasteful .......................... 379

C. Consumer as Nonsensical ........................ 381

III. The Consumer Bias ............................ 382

A. Implicit Bias ............................... 382

B. Linguistic Bias ............................ 383

C. Consumer Bias ............................ 385

IV. Rethinking Trademark Law's Consumer Label ... 388

A. The Gullible Consumer ...................... 389

B. The Silent Consumer....................... 394

C. The Trademark Citizen ....................... 399

V. Conclusion .................................... 401

\section{INTRODUCTION}

The immense mechanism, set up by man to produce objects for his use, transforms man himself into an object used by the same mechanism of production and consumption.

All of us are labeled consumers. Our product-related activities are referred to as consumption. We are told that we live in a consumer society, and we engage with a consumer culture. ${ }^{2}$ It is unsurprising, then, that our trademark law uses the term consumer constantly, reflexively, and unconsciously to refer to its subjects—us, the purchasing public. ${ }^{3}$

The "reasonably prudent consumer" is trademark law's principle construct-like the reasonable person in tort, the author in copyright, or the PHOSITA ${ }^{4}$ in patent law. ${ }^{5}$ It would be impossible to overstate the extent to which trademark law makes use of the consumer label. ${ }^{6}$

1. Paul Tillich, The Lost Dimension of Religion, in Adventures of THE Mind 1, 3 (Mark Van Doren ed., 1959).

2. See, e.g., Michael Dawson, The Consumer Trap: Big Business MarketING IN AMERICAN LIFE 15 (2003).

3. See infra Part II.

4. The acronym for a "person having ordinary skill in the art." See Naina Gulati \& Jasmeet Gulati, Knowledge/Skill Standards of a "Person Skilled in Art": A Concern Less Visited, 17 J. Marshall Rev. Intell. Prop. L. 588, 589 (2018).

5. See Laura A. Heymann, The Reasonable Person in Trademark Law, 52 ST. Louis U. L.J. 781, 782 (2008); Barton Beebe, Search and Persuasion in Trademark Law, 103 Mich. L. Rev. 2020, 2022-23 (2005).

6. E.g., William McGeveran \& Mark P. McKenna, Confusion Isn't Everything, 89 Notre Dame L. Rev. 253, 254 (2013) ("Ask any law student to describe the purpose of trademark law and you're likely to get a simple answer: preventing consumer confusion. Indeed, you'd likely get the same simple answer from most trademark lawyers." (emphasis added)). 
The U.S. Supreme Court, in its recent Iancu v. Brunetti decision, remarked that trademark law has "a specialized mission: to help consumers identify goods and services they wish to purchase, as well as those they want to avoid." " And as one leading commentator puts it, "trademarks are a property purely of consumers' minds"; "the consumer, we are led to believe, is the measure of all things in trademark law."

As "a form of consumer protection," jor doctrines revolves around consumer perceptions, thus identifying the consumer as the source of all of its internal boundaries. ${ }^{10}$ According to the dominant law-and-economics-based account of trademark law, the "fundamental purpose of a trademark is to reduce consumer search costs by providing a concise and unequivocal identifier of the particular source of particular goods." 11

To this end, all of trademark law's doctrines invoke the consumer mindset. Trademark infringement is decided based on whether "an appreciable number of consumers are likely to be confused by the defendant's use of its mark." 12 Trademark distinctiveness asks whether a mark "requires 'imagination, thought and perception' for consumers to reach a conclusion as to the nature of its corresponding product or service." 13 The trademark use requirement demands that a mark be "featured in a way that will draw consumers' attention to it and lead them to view it as a source indicator." 14 Trademark dilution "grants trademark holders an injunctive remedy for the use of their famous marks by another even when consumers are not confused." 15

Initial interest confusion allows liability for "trademark infringement solely on the basis that a consumer might initially be interested, attracted, or distracted by a competitor's, or even a non-competitor's,

7. Iancu v. Brunetti, 139 S. Ct. 2294, 2306 (2019) (Breyer, J., concurring \& dissenting in part) (emphasis added).

8. Beebe, supra note 5, at 2021 (emphasis added).

9. J. Thomas McCarthy, McCarthy on Trademarks and Unfair CompeTITION § 19:1.75 (5th ed. 2019).

10. Rebecca Tushnet, Registering Disagreement: Registration in Modern American Trademark Law, 130 HARV. L. REV. 867, 878 (2017) ("In the current version of trademark law, all of the internal boundaries of protectability are based on consumer understanding.").

11. Ty Inc. v. Perryman, 306 F.3d 509, 510 (7th Cir. 2002); see also William M. Landes \& Richard A. Posner, Trademark Law: An Economic Perspective, 30 J.L. \& ECON. 265, 268-70 (2014).

12. Robert G. Bone, Taking the Confusion Out of "Likelihood of Confusion": Toward a More Sensible Approach to Trademark Infringement, 106 Nw. L. REv. 1307, 1307 (2012) (emphasis added).

13. Dustin Marlan, Visual Metaphor and Trademark Distinctiveness, 93 WASH. L. Rev. 767, 799 (2018) (emphasis added) (quoting Stix Prods., Inc. v. United Merchs. \& Mfrs., Inc., 295 F. Supp. 479, 488 (S.D.N.Y. 1968)).

14. Alexandra J. Roberts, Trademark Failure to Function, 104 Iowa L. REv. 1977, 1977 (2019) (emphasis added).

15. Clarisa Long, Dilution, 106 Colum. L. Rev. 1029, 1029 (2006) (emphasis added). 
product or service."16 Point-of-sale confusion "occurs when consumers believe their products to be the same as a company which it is not."17 Once a trademark is incontestable, "it does not matter how much proof a challenger offers that the symbol at issue is perceived by consumers as merely descriptive of the registrant's goods or services and not as a trademark." ${ }^{18}$ Post-sale confusion is rationalized "on the basis that consumers need to be protected in their investment in prestigious brands," 19 and false advertising law requires that a misrepresentation "is likely to affect consumers' purchasing decisions."

Given such omnipresent emphasis on the consumer, the term is used dozens, and sometimes even hundreds, of times in any single trademark-related document-case opinions, treatises and practice books, trial and appellate briefs, law review articles, and by the United States Patent and Trademark Office. Indeed, trademark law requires the capability "to think through the consumer and see the marketplace only as the consumer sees it." 21

Much criticism has been rightly levied against trademark law's treatment of the consumer as a purely economic creature-passive, ignorant, and gullible. ${ }^{22}$ For instance, Laura Heymann writes that trademark treats the purchaser "as one who 'consumes'-one entitled at most to a negative freedom from confusion without the benefit of

16. Jennifer E. Rothman, Initial Interest Confusion: Standing at the Crossroads of Trademark Law, 27 CARdozo L. Rev. 105, 108 (2005) (internal quotations omitted) (emphasis added \& omitted).

17. Polaroid Corp. v. Polarad Elecs. Corp., 287 F.2d 492, 495 (2d Cir. 1961).

18. Rebecca Tushnet, Fixing Incontestability: The Next Frontier?, 23 B.U. J. ScI. \& TeCH. L. 434, 438 (2017) (emphasis added).

19. Graeme W. Austin, Trademarks and the Burdened Imagination, 69 BRoOK. L. REv. 827, 835 (2004) (emphasis added).

20. Mark A. Lemley \& Mark McKenna, Irrelevant Confusion, 62 StAN. L. Rev. 413, 415-16 (2010) (emphasis added).

21. Beebe, supra note 5, at 2022 (emphasis added).

22. See, e.g., Robert C. Denicola, Institutional Publicity Rights: An Analysis of the Merchandising of Famous Trade Symbols, 62 N.C. L. REv. 603, 608 (1984) (noting that several consumer confusion cases rhetorically "characterize the relevant consumer group, or some unfortunate subset thereof, as 'ignorant,' 'unthinking,' or 'credulous[ ]",); Ann Bartow, Likelihood of Confusion, 41 SAN Diego L. REv. 721, 782 (2004) ("The theory of consumer-as-idiot prevails in many trademark infringement cases, often seeming glaringly pretextual ....."); Laura A. Heymann, The Public's Domain in Trademark Law: A First Amendment Theory of the Consumer, 43 GA. L. REv. 651, 655 (2009) (explaining that trademark law views "consumers as passive receivers of information rather than active participants in a trademark dialogue"); Beebe, supra note 5, at 2072 ("The consumer, once sovereign, has been deposed, deprivileged, decentered ...."); Austin, supra note 19, at 829 ("The law assumes that the ordinarily prudent consumer unthinkingly accepts the messages trademark proprietors seek to enforce through their branding strategies ...."); Deborah R. Gerhardt, Consumer Investment in Trademarks, 88 N.C. L. REV. 427, 438 (2010) ("Th[e] impulse to define consumer confusion in a way that protects trademark owners has resulted in years of trademark discourse that demeans consumers and devalues their interests."). 
any positive theory that actively carves out space for her role in the trademark conversation." 23 And, as Ann Bartow asks:

Why, in trademark litigation decisions, do judges so often write about representative members of the public as if we are astoundingly naïve, stunningly gullible, and frankly stupid? Do jurists truly believe that consumers are complete idiots? What is it about trademark law that seems to elicit from courts such offensive and humiliating views of the citizenry? ${ }^{24}$

This Article suggests that the linguistic bias stemming from the law's label of the buying public as mere consumers - rather than, for instance, citizens, persons, individuals, or human beings-could be a contributing factor to trademark law's condescending view of its subjects.

For instance, in an opinion now cited nearly 500 times, the Seventh Circuit remarked: "Many consumers are ignorant or inattentive, so some are bound to misunderstand no matter how careful a producer is." 25 Imagine if the word consumer in that sentence was replaced by a word like individual or citizen instead. The likelihood that a judge would frame the issue in such a derogatory manner would seem to drop significantly.

This Article urges those involved with trademark and advertising law-e.g., judges, lawyers, lawmakers, and academics - to rethink our ubiquitous use of the derogatory consumer label. The metaphorical use of the term consumer is dehumanizing, anti-ecological, and nonsensical. As one commentator puts it:

People are more than just consumers. Consumption activities most directly address living standard (or lifestyle) goals, which have to do with satisfying basic needs and getting pleasure through the use of goods and services. But people are often interested in other goals, such as self-realization, fairness, freedom, participation, social relations, and ecological balance. To some extent, these goals may be attained through consumption, but often they conflict with their goals as consumers. ${ }^{26}$

Further, social psychology experiments find that using the word consumer has potentially deleterious consequences for society given the negative stereotypes it engenders as a social categorization ${ }^{27}$ For instance, in one study, participants were presented with the following

23. Heymann, supra note 22, at 656 .

24. Bartow, supra note 22, at 723 (emphasis added).

25. August Storck K.G. v. Nabisco, Inc., 59 F.3d 616, 618 (7th Cir. 1995) (emphasis added); see also Fotomat Corp. v. Cochran, 437 F. Supp. 1231, 1244 (D. Kan. 1977) ("The law protects the gullible and ignorant consumer as much as the careful and intelligent consumer.").

26. Neva Goodwin et Al., Principles of Economics in Context 191 (2014) (emphasis added).

27. Monika A. Bauer et al., Cuing Consumerism: Situational Materialism Undermines Personal and Social Well-Being, 23 Ass'N fOR Psych. SCI. 517, 522 (2012). 
hypothetical: there is a water shortage, and the participants must share a drinking well. ${ }^{28}$ Half of the participants were labeled consumers and the other half were referred to as individuals. ${ }^{29}$ According to a press release about the study: "The 'consumers' rated themselves as less trusting of others to conserve water, less personally responsible, and less in partnership with the others in dealing with the crisis. The consumer status, the authors concluded, 'did not unite; it divided." "30

In mapping these findings onto trademark law, consider by analogy that several commentators have previously discussed the dangers of using the term "intellectual property" given the loaded nature of the word "property." 31 Philosopher Samir Chopra writes:

[Property] is regarded as the foundation of a culture and as the foundation of an economic system.... It has ideological weight and propaganda value. To use the term 'intellectual property' is to partake of property's expressive impact in an economic and political order constructed by property's legal rights. It is to suggest that if property is at play, then it can be stolen, and therefore must be protected with the same zeal that the homeowner guards her home against invaders and thieves. ${ }^{32}$

As such, the term property obscures the realization that beyond the party that "owns" the intellectual property right, there is an excluded public domain whose interests are not being rhetorically accounted for by use of the term. ${ }^{33}$

28. Id.

29. Id. at 521 .

30. Ass'n for Psych. Sci., Consumerism and Its Antisocial Effects Can Be Turned On-Or Off, ScIENCEDAILy (Apr. 9, 2012), https://www.sciencedaily.com/releases/ 2012/04/120409175915.htm [https://perma.cc/6Q65-379V] (emphasis added).

31. Samir Chopra, End Intellectual Property, AEON (Nov. 12, 2018), https:// aeon.co/essays/the-idea-of-intellectual-property-is-nonsensical-and-pernicious [https:// perma.cc/75VE-84EC]; see also Richard M. Stallman, Did You Say 'Intellectual Property'? It's a Seductive Mirage, 4 PoL'y Futures Educ. 334 (2006) (arguing that we should stop using the term intellectual property); $c f$. James Boyle, The Public Domain: Enclosing the Commons of THE Mind 8 (2008) (noting that the concerns with the term "intellectual property" are "real and well-founded" but disagreeing with the conclusion that we should give up the term considering its usefulness as an umbrella category).

32. Chopra, supra note 31.

33. See, e.g., Madhavi Sunder, $I P^{3}$, 59 Stan. L. Rev. 257, 332 (2006) ("A cultural theory of intellectual property recognizes not only the symbiotic relationship between technology and intellectual property, but also views intellectual property-including its technology policy-within a context of cultural development and social movements . . ..”); Sonia K. Katyal, Semiotic Disobedience, 84 WAsh. U. L. REv. 489, 490 (2006) ("Instead of relegating the audience to passive spectatorship, a semiotic democracy would empower individuals to add to the rich and expansive cultural fabric of a true public domain, where everyone participates equally in the ongoing process of cultural production."); Keith Aoki, How the World Dreams Itself To Be American: Reflections on the Relationship Between the Expanding Scope of Trademark Protection and Free Speech Norms, 17 Loy. L.A. ENT. L. REV. 523, 528 (1997) ("The significance of trademarks, as the embodiment of textual meaning, dramatically increases 
Similarly, the term consumer, in its invocation of passive consumption, rhetorically obscures the reality of trademark law as a regime that should serve a population who increasingly must take an active role within a complex cultural system of trade symbols. ${ }^{34}$ Indeed, by its all-pervading use of the consumer label, trademark law objectifies its subject-us, the capitalist public. ${ }^{35}$ The public, in fact, does not even hold standing to sue under the Lanham Act (the Trademark Act of 1946). ${ }^{36}$

In delving deeper into these issues, this Article urges a heightened consciousness around use of the term consumer, including in trademark and advertising law. Part II discusses the use of consumer as a metaphor-finding that it invokes passivity and wastefulness and is also nonsensical and absurd as a descriptor. Part III explores the concepts of implicit bias and linguistic bias. It then applies these concepts specifically to the term consumer through discussion of the above-referenced psychology experiments, finding that consumer leads to bias and stereotype as a social categorization. Part IV maps the consumer bias onto trademark law, finding that the biasing effects of consumer may be contributing to trademark law defining the public in a manner that is patronizing, biased, insulting, and indulgent of likelihood-ofconfusion claims. The Article then concludes by urging those involved with trademark and advertising law to follow one of two approaches: (1) take active steps to phase out use of consumer and replace it with more respectful and appropriate terminology such as citizen; or (2) simply maintain the status quo in using consumer, but each time be

within the context of postmodernity due to proliferation of commodified symbols as objects of consumption resulting from the uncoupling of the real and the symbolic.").

34. See, e.g., Margaret Chon, Slow Logo: Brand Citizenship in Global Value Networks, 47 U.C. DAvis L. REV. 935, 948 (2014) ("The growing literature on the construction of brands shows that the goodwill represented by a mark is not produced solely through a firm that technically owns the trademarks rights, but is rather a social creation involving contributions by many actors and participants in this era of cognitive or information capitalism."); Gerhardt, supra note 22, at 436 ("[T]rademark discourse too often ignores both the extent to which consumers shape trademark value and how public interests in the informational value of marks should be reflected in trademark doctrine."); Katya Assaf, The Dilution of Culture and the Law of Trademarks, 49 IDEA 1, 4-5 (2008) ("When the law allows owners of trademarks . . . to 'freeze' the meaning of the signs they own, it deprives other members of society the ability to take part in shaping their culture.").

35. Much like it subjectifies its object-the trademark itself-through intuitiondependent doctrines like distinctiveness and the likelihood-of-confusion analysis. See generally Beebe, supra note 5.

36. See Impression Prods., Inc. v. Lexmark Int'l, Inc., 137 S. Ct. 1523, 1529 (2017) (holding that consumers cannot sue for false advertising under the Lanham Act); see also Michael Grynberg, Trademark Litigation as Consumer Conflict, 83 N.Y.U. L. REv. 60, 56 (2008) (noting that trademark owners, rather than consumers, have long been the parties to file the lawsuits under the Lanham Act). But see Curtin v. United Trademark Holdings, Inc., 2018 WL 4183136 (T.T.A.B. 2018) (finding that consumer had standing to challenge registration of RAPUNZEL mark for dolls). 
conscious of the biasing effects that the consumer construct may have for the law and us as its subjects.

\section{The Consumer Metaphor}

This Part explores the term consumer as a disparaging, insulting, and offensive metaphor ${ }^{37}$ for "one that utilizes economic goods." 38 According to sociologist and author Raymond Williams:

The popularity of 'consumer' as a contemporary term deserves some attention. It is significant because, first, it unconsciously expresses a really very odd and partial version of the purpose of economic activity (the image is drawn from the furnace or the stomach, yet how many things there are we neither eat nor burn), and, second, it materializes as an individual figure (perhaps monstrous in size but individual in behavior) - the person with needs which he goes to the market to supply. ${ }^{39}$

"Consumption" entered discourse already with a "heavy burden," given its roots in the exhaustion of resources. ${ }^{40}$ The term is derived from the Latin "consumere," meaning "to destroy, wear away, to kill, annul, extinguish, wear down, exhaust, to eat, devour, to take (a medicine), use up, expend, swallow up, merge, to spend (money, resources or time), waste, squander." ${ }^{41}$ Consumer first moved from Latin to French in the twelfth century, and then into English and other European languages in the fifteenth century. ${ }^{42}$ When it first entered the English vernacular along with the related "consume" and "consumption," consumer was initially defined in a literal fashion as

37. Metaphor is not simply a description; it is an act of conceptualization. The use of one thing, in other words, to symbolically represent another. "The essence of metaphor is understanding and experiencing one kind of thing in terms of another." George Lakoff \& Mark Johnson, Metaphors We Live By 145-46 (1980).

38. The other definition listed for consumer is less metaphorical and more literal: "[A]n organism requiring complex organic compounds for food which it obtains by preying on other organisms or by eating particles of organic matter." Consumer, MERRIAM-WEBSTER, https://www.merriam-webster.com/dictionary/consumer [https:// perma.cc/F4HL-YR9X].

39. Raymond Williams, The Long Revolution 322 (1961) (emphasis added).

40. Frank Trentmann, How Humans Became 'Consumers': A History, The ATLANTIC (Nov. 28, 2016), https://www.theatlantic.com/business/archive/2016/11/howhumans-became-consumers/508700/ [https://perma.cc/4ZES-N69Z] [hereinafter Trentmann, How Humans Became Consumers]; see also Frank Trentmann, Empire of Things: How We Became a World of Consumers, from the Fifteenth CenTURY TO THE TWENTY-First 70-71 (2016) (noting the global change in consumption in the "late-seventeenth and eighteenth-century Europe"- "volume, variety[,] and innovation" characterized this "new regime") [hereinafter TrEnTMANN, EMPIRE OF THINGs].]

41. Josh MacKinnon, What Will the Great Pause Mean for Consumerism?, MEDIUM: The STARTUP (July 14), https://medium.com/swlh/what-will-the-great-pausemean-for-consumerism-163699f5356 [https://perma.cc/JKU9-XNBV]; see THE NEW OXford American Dictionary 365-66 (Erin McKean et al. eds., 2d ed. 2005); D.P. Simpson, Cassell's Latin Dictionary 144 (5th ed. 1968).

42. Trentmann, How Humans Became Consumers, supra note 40. 
"using up, wasting, and finishing." ${ }^{43}$ People associated consumption with the human body, which could be "consumed" by disease. Tuberculosis-the "wasting disease" - was also referred to as consumption. ${ }^{44}$ Its sinister synonyms include "wasting away," "finishing," "depletion," and "exploitation." 45 In effect, consume meant "to use something and then get rid of it." 46

In the past, such macabre meanings informed how pre-modern governments regulated the consumption of their citizens. ${ }^{47}$ In fact, between the fourteenth and eighteenth centuries, European states and, by extension, their American colonies, enacted various sumptuary laws intended to limit fineries and fashions. ${ }^{48}$ For instance, the Venetian Senate banned gilded mirrors and chests and forbade gifting more than six forks and spoons as wedding presents. ${ }^{49}$ In the 1700 s, citizens in German states were fined or jailed for wearing cotton neckerchiefs. ${ }^{50}$ Such a restrictive view of products made a certain amount of sense in societies which, prior to the era of sustained growth, had limited resources and finances, and were morally and religiously astute. ${ }^{51}$ Thus, "consumers . . . were seen as 'fickle and a drain on wealth." 52 But economic theories began to change.

Bernard Mandeville, in his seminal poetic text, The Fable of the Bees: Or Private Vices, Publick Benefits, ${ }^{53}$ and in a series of prose es-

43. Id.

44. Id.

45. See id.

46. See id.

47. Id.

48. Id. For an analysis of sumptuary laws and intellectual property, see Barton Beebe, Intellectual Property Law and the Sumptuary Code, 123 HARv. L. Rev. 809 (2010).

49. Trentmann, How Humans Became Consumers, supra note 40.

50. Id.

51. Id.

52. $I d$.

53. F. B. Kaye, Introduction to Bernard Mandeville, The Fable of the Bees: Or Private Vices, Publick Benefits, at xlvi-xlvii (Liberty Fund, Inc. 1988) (1714). Mandeville's moral provided an analogy to a beehive losing its vices yet at the same time losing its greatness:

THEN leave Complaints: Fools only strive

To make a Great an Honest Hive.

T' enjoy the World's Conveniences,

Be fam'd in War, yet live in Ease,

Without great Vices, is a vain

EUTOPIA seated in the Brain.

Fraud, Luxury and Pride must live,

While we the Benefits receive. . .

So vice is beneficial found,

When it's by Justice lopt and bound;

Nay, where the People would be great,

As necessary to the State,

Id.

As Hunger is to make 'em eat. 
says that followed, advanced his influential thesis "that vice [was] the foundation of national happiness and prosperity." 54 That is, public benefit (e.g., wealth) must be based on private vice (e.g., consumption). ${ }^{55}$ Then in 1776, Adam Smith, in his An Inquiry into the Nature and Causes of the Wealth of Nations, wrote: "Consumption is the sole end and purpose of all production; and the interest of the producer ought to be attended to, only so far as it may be necessary for promoting that of the consumer." 56 And economic theories began proposing that value was created by the consumer and not only by the producer. ${ }^{57}$ In other words, the value of a product depended on how much a person desired it. ${ }^{58}$ In 1871, for instance, William Stanley Jevons published his Theory of Political Economy, noting that a "theory of economics must begin with a correct theory of consumption." 59

Consumer, soon after, was labeled the opposite of producer, coming to mean "one who uses up goods or articles." ${ }^{\circ 0}$ And in about 1890, the term consumer goods entered economic vocabulary. ${ }^{61}$ Thus, consumer came to be commonly associated with the purchasing of material goods by individuals. In the popular vernacular, consumer debuted, quite fittingly, as the title of the Sears, Roebuck and Company catalog in the late $1800 \mathrm{~s} .{ }^{62}$ During the $1890 \mathrm{~s}$, consumer started to make its way into case law decisions, including in trademark law. ${ }^{63}$ It eventually overtook use of "purchaser" and "customer" a century later. ${ }^{64}$ Today,

54. Id. at xlvii.

55. Id. at xlviii.

56. Adam Smith, An Inquiry into the Nature and Causes of the Wealth of Nations 244 (James E. Thorold Rogers ed., London MacMillan \& Co. 1869) (1776).

57. Trentmann, How Humans Became Consumers, supra note 40.

58. $I d$.

59. W. Stanley Jevons, Theory of Political Economy 43 (2d ed. 1879).

60. Douglas Harper, Consumer, Online Etymology Dictionary, https:// www.etymonline.com/word/consumer\#etymonline_v_28735 [https://perma.cc/LUP7TN52].

61. Id.

62. Michael Dawson, "Consumption": Epic Vocab Fail: The Bias of the Consumer Vocabulary, The CONSUMER TrAP (Oct. 8, 2014), https://www.consumertrap.com/ consumer-bias/ [https://perma.cc/V25F-3MX4].

63. Columbia Mill Co. v. Alcorn, 150 U.S. 460, 462 (1893) ("[P]urchasers and consumers thereof were misled and deceived by the defendants, who put up in similar packages an imitation of the flour manufactured by the complainant, which was thus sold by them under the name, brand, and trade-mark, 'Columbia." (emphasis added)); Meyer v. Dr. B.L. Bull Vegetable Med. Co., 58 F. 884, 884-85 (7th Cir. 1893) (remarking that the trademarks " 'Bull's Cough Syrup' and 'Dr. Bull's Cough Syrup'” became "widely known and identified by consumers and the public" (emphasis added)); Schmidt v. Brieg, 35 P. 623, 624 (Cal. 1893) ("The article has become widely known to the public and to buyers and consumers thereof as the beverage manufactured and sold by the plaintiffs, not only through the name 'Sarsaparilla and Iron,' but through said labels." (emphasis added)).

64. Historical Trends, Caselaw Access Project at Harvard Law School, https://case.law/trends/?q=consumer,\%20customer,\%20purchaser \&xy=2015 [https:// perma.cc/A6BB-KS2E]. 
consumer is routinely used instead of people, citizens, and similar terms both in a general sense and in legal discourse. ${ }^{65}$ That is, individuals in our "consumer society" are frequently labeled consumers; product-related activities are referred to as consumption. ${ }^{66}$

As a metaphor, consumer is now being increasingly recognized as problematic given: (1) its connotation of humans as reductive marketbased objects; (2) its anti-ecological bent; and (3) its nonsensical nature. The following three Subsections will discuss these problems in turn, with the takeaway that the consumer metaphor is stigmatic, and its use as a label is thus capable of creating a negative stereotype.

\section{A. Consumer as Dehumanizing}

Perhaps the most salient objection to the term consumer is the dehumanization, reduction, and objectification of the buying public, which the term connotes. The consumer label evokes humans "as objects instead of personifying them as real living, breathing people." 67 The role of the consumer is merely economic, passive, and recessive. As essayist William Deresiewicz puts it:

The word you hear most often is consumers. We are all consumers. Which means what? That our main job, in this enterprise that we all share, is to use stuff up. Not a political role at all, but only an economic, and what's more, a passive or recessive-an, as it were, alimentary-one. We aren't even workers, which sounds too militant,

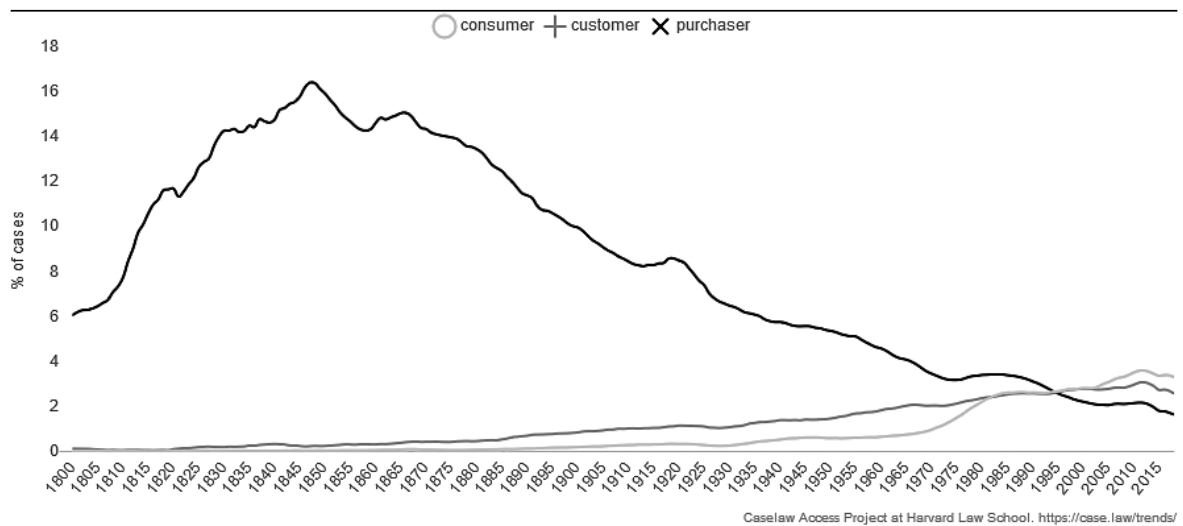

65. Steven Moore, Why Is "Consumer" a Bad Word?, Network fOr Bus. SusTAINABILITY (Jan. 20, 2020), https://www.nbs.net/articles/why-is-consumer-bad-word [https://perma.cc/L2LJ-UKH2] (reporting "that 'consumer' is now often used interchangeably with 'person' in the [ten] most commonly used languages of the world.").

66. Dawson, supra note 2, at 4.

67. Don Norman, Words Matter. Talk About People: Not Customers, Not Consumers, Not Users, JND.ORG (Dec. 3, 2018), https://jnd.org/words_matter_talk_about_people_not_customers_not_consumers_not_users/ [https://perma.cc/99U9-MKGN]. 
only consumers. Our chief responsibility is just to keep on swallowing. ${ }^{68}$

Yet such passivity is increasingly inaccurate:

"Consumer" . . . relegates people to a passive role. Speaking of them this way defines them only by their gaping maw, and thus, we think in terms of what we can do to get them to eat more rather than what they might want to do for themselves. The business is the active producer, and the consumer, the compliant, er. . . consumer. This in an era when people are empowered to produce in more ways than ever before, engaging as active critics, advocates, organizers, curators, or co-creators with the products or services they care about. ${ }^{69}$

Consumer rhetorically confines the individual to purely market-focused matters. Indeed, when humans "are framed as consumers, society becomes little more than a marketplace." ${ }^{70}$ Donald Norman, author of The Design of Everyday Things, believes that product designers, in particular, distance themselves from the people they design for by referring to them by the degrading term consumer ${ }^{71}$ The consumer label, Neil Parker writes, "gives us a partial view of people, impairing our ability to think creatively about how to serve them better," given that the focus remains "narrowly on the purchase and use of [a] product in isolation." 72 In contrast, considering a purchaser as a "person rather than as a consumer changes your perspective and helps you see people in a broader way." 73

Citizen rights activist Jon Alexander warns that as the consumer becomes the principal role for individuals in society, consumption becomes the defining act of participation in society. ${ }^{74}$ As such, the "word [c]onsumer represents the idea that all we can do is consume, choosing between the options offered us." 75 Further, each "time we see an ad that asks us only to transact, that prominence is being reinforced;

68. William Deresiewicz, Words to Live By, Am. SchOlar (June 20, 2011), https:// theamericanscholar.org/words-to-live-by/\#.XWwSTnt7m00 [https://perma.cc/C7YLESYL].

69. Neil Parker, Five Reasons to Kill the Word 'Consumer' Right Now, Forbes (Dec. 8, 2015, 1:36 PM), https://www.forbes.com/sites/onmarketing/2015/12/08/fivereasons-to-kill-the-word-consumer-right-now/\#6f4c81e241f5 [https://perma.cc/N2RUE6GW].

70. Jathan Sadowski, Stop Treating Citizens Like Consumers, Al Jazeera Am. (July 5, 2015, 2:00 AM), http://america.aljazeera.com/opinions/2015/7/stop-treatingcitizens-as-consumers.html [https://perma.cc/989Q-GVMN].

71. See generally Donald Norman, The Design of Everyday Things (2013).

72. Parker, supra note 69.

73. Jonah Bloom, The Dirtiest Word in Business? Consumers, Fast Company (Sept. 19, 2018), https://www.fastcompany.com/90238754/the-dirtiest-word-in-business-consumers [https://perma.cc/WXP7-7DHN].

74. Jon Alexander, Viewpoint: How the Consumer Dream Went Wrong, BBC (Oct. 29, 2014), https://www.bbc.com/news/magazine-29786733 [https://perma.cc/ $8 X X P-J Z B C]$.

75. $I d$. 
we are being told we are Consumers and that how we spend our money is the extent of our power in the world."76 Since the Great Recession of 2008, the backlash against consumerism has included resistance among the public to the consumer label itself. According to one anonymous online commenter at Democratic Underground:

The way that the media and these [W]all [S]treet douchenozzles bandy the word "consumer" and use it to generally apply to any person who ever buys anything (IE all of us) completely disgusts me. It reduces all of us to market forces and resources to be bought and sold, and to be held in little more respect and with little more consideration than that which is granted to livestock, or ore bearing rocks. ${ }^{77}$

They continue: "A consumer is nothing more than a mindless resource to be exhausted and discarded. A citizen," in contrast, "is a free-thinking, free willed individual with rights and the power to tell [W]all [S]treet to go collectively roger itself." ${ }^{\prime 78}$ Another Democratic Underground user agrees:

Talk about dehumanization- "you are what you buy." . . . It makes sense, in a perverted way, that corporate executives and their spokespeople in the mass media universe refer to people as "consumers." It's almost as if they are projecting their own massive consumption of the world's wealth and resources onto the vast majority of people who aren't rich-much of the "buying public," in other words. $^{79}$

Indeed, the word consumer is "reductive, at best. And it speaks volumes about what our proper role [is] considered to be." 80

\section{B. Consumer as Wasteful}

Consumer also has an anti-ecological bent- "consumers sound like ravening beasts who must destroy what they buy instead of renting it

76. Jon Alexander, The 'Just Go Shopping' Message from Advertisers Has a Dangerous Effect, GuARDiAn (Jan. 10, 2014, 11:11 AM), https://www.theguardian.com/ sustainable-business/behavioural-insights/just-go-shopping-message-advertisers-dangerous-effect [https://perma.cc/RT3B-FK8B].

77. Indenturedebtor, I'm Not a "Consumer" I'm a Citizen!, DemocraticUnderGROUND.COM (Sept. 17, 2009, 1:46 AM), https://web.archive.org/web/20151230051633/ http://www.democraticunderground.com/discuss/duboard.php?az=view_all\&address= 389x6569048 [https://perma.cc/SEA2-LPME?type=image].

78. $I d$.

79. YoungDemCA, Comment to I Hate It When People Are Referred to As "Consumers". . . ., DemocraticUnderground.com (Sept. 21, 2013, 9:34 PM), https:// upload.democraticunderground.com/10023709342 [https://perma.cc/QQB5-W5P4].

80. caraher, Comment to I Hate It When People Are Referred to As "Consumers". . . ., DemocraticUnderground.com (Sept. 21, 2013, 12:34 AM), https:// upload.democraticunderground.com/10023709342 [https://perma.cc/QQB5-W5P4]. 
from the recycler." ${ }^{\prime 1}$ Even in an era where society views climate change as one of our most pressing concerns, the word consumer is "used more often in a business context than the words it stands in for: people, individuals, humans." 82 And while society is increasingly more vigilant regarding political correctness in terms of social categorizations, it remains perfectly acceptable to habitually label citizens as consumers-"mere money spending garbage disposals, mere programmable units for buying and using up the firm's wares." 83

Raymond Williams believes that the consumer description became increasingly popular as "a considerable and increasing part of our economic activity goes to ensuring that we consume what industry finds it convenient enough to produce." ${ }^{84}$ But it is now "obvious that society is not controlling its economic life, but is in part being controlled by it." 85 As Victor Lebow remarked: "Our enormously productive economy ... demands that we make consumption our way of life, that we convert the buying and use of goods into rituals, that we seek our spiritual satisfaction, our ego satisfaction, in consumption ... we need things consumed, burned up, replaced, and discarded at an ever-accelerating rate." $" 86$

According to Patagonia's Vice President Rick Ridgeway, the word consumer prevents us from being mindful of environmental degradation:

At Patagonia, we hate the word "consumers." We've got to find a better word, we prefer "customers," and we prefer also customers who recognize the impact of their consumption. They recognize that as consumers, they're part of the problem. We are hopeful that we can encourage customers to join us in really questioning consumption. Because without a reduction in consumption, we don't feel that we'll really collectively find a solution to the problems we face, that are collectively, year by year, resulting in the continued decline of the health of our planet. ${ }^{87}$

Blogger Tabitha Whiting warns that as we have come to self-identify as consumers, we are creating a culture in which "attaining of material wealth takes precedence over ensuring the welfare of others and of

81. Grant McCracken, "Consumers" or "Multipliers" a New Language for Marketing?, CultureBy (Nov. 10, 2005), https://cultureby.com/2005/11/consumers_ or_mu.html [https://perma.cc/4YZJ-HA47].

82. Bloom, supra note 73 .

83. Dawson, supra note 2, at 4-5.

84. Williams, supra note 39, at 297.

85. Id.

86. Gregg Koep, Victor Lebow: Journal of Retailing Spring 1955, Blogspot: Not BUYING ANYTHING, https://notbuyinganything.blogspot.com/p/price-competition-in1955-victor-lebow_27.html [https://perma.cc/JP4C-MFK2].

87. Bullfrog Films, The True Cost, DocusEeK (2015), http://docuseek2.com/bftrue [https://perma.cc/85UV-4XLP] (advance video to 00:43:13). 
the community." 88 And Andrew Bennet and Ann O'Reilly, authors of Consumed: Rethinking Business in the Era of Mindful Spending, write:

\begin{abstract}
Along with economists, politicians, business reporters, and advocacy groups, we habitually describe our fellow humans as consumers. Of course, that term makes sense when applied to people wolfing down food and drink, but lately it has been extended to virtually every area of our lives. Nowadays we do not just consume hot dogs and Cokes; we consume services and environmental resources and media and durable goods and everything else imaginable, all with greedy gusto and a seemingly bottomless appetite. Until recently, just about everyone accepted this insidious new moniker, perhaps not even noticing when the term consumer began to push aside references to ourselves as citizens or simply men and women. ${ }^{89}$
\end{abstract}

\title{
C. Consumer as Nonsensical
}

In addition to its stigma as reductive and wasteful, the consumer label is also nonsensical and absurd. Michael Dawson, author of The Consumer Trap: Big Business Marketing in American Life, claims that describing the process of shopping, purchasing, transporting, preparing, and maintaining a product by the ultimate end of "consumption" is analogous to labeling the process of life as "death," and humans as "die-ers." J0 Just as the vast majority of people aim to avoid death for as long as possible, "ordinary people are product users who generally rue and work to minimize the consumption of goods and services" for various financial, ecological, or sentimental reasons. ${ }^{91}$ In contrast to consumption - the ultimate using up of a good or service-normal and healthy goals of product users include pleasure, longevity, usefulness, and cost-minimization. ${ }^{92}$ Dawson writes:

[D]o we roll our cars off cliffs to see them explode? Do we scramble to pour our just-brought beverages out in the grocer's parking lot? Do we rush home to smash our appliances with sledgehammers, then burn the sledgehammers in our fireplaces, then allow fire to burn down our houses-all to maximize our destruction-our consumption - of goods? Of course we don't. We gas and fix our cars, cap and refrigerate our undrunk beverages, and care for our homes and appliances until upgrade becomes possible or further repair becomes irrational or impossible. Whenever possible, we strive to counteract product wear and tear, which is ordinarily an unin-

88. Tabitha Whiting, When Did We Stop Being 'Citizens' and Become 'Consumers'?, Medium (May 8, 2019), https://blog.usejournal.com/when-did-we-stop-being-citizens-and-become-consumers-6176f3424dd0 [https://perma.cc/GPH8-Y5MA].

89. Andrew Bennet \& Ann O'Reilly, Consumed: Rethinking Business in the Era of Mindful Spending ix (2010).

90. Dawson, supra note 2, at 5-6.

91. Id. at 6 (emphasis removed).

92. Id. at 4. 
tended, costly, and regretted consequence of our product usage, not its goal. ${ }^{93}$

Moreover, the ultimate act of consumption, Dawson notes, benefits producers, brands, and corporations that are able to sell more only when people purchase a previous product or service and then subsequently exhaust it - thus, at the literal expense of consumers. ${ }^{94}$ Dawson further suggests that "product destruction is neither an aim of nor a benefit to us 'consumers' is both a point to be suppressed (at least at the level of public discourse) and a business problem to be managerially overcome." 95 To this end, consumer describes desired behavior from the perspective of large private corporations; it does not help us understand it from the perspective of the individual.

\section{The CONSUMER Bias}

This Part contends that the term consumer may not only be insulting-reductive, anti-ecological, and nonsensical-but also quantitatively harmful given the implicit linguistic bias generated by use of the term. Consistent with social psychological findings, the word consumer, as a social categorization, has the ability to create negative inferences and stereotypes. In turn, these stereotypes can alter the behavior of those labeled, as well as those who engage in the labeling.

\section{A. Implicit Bias}

Over the past couple decades, there has been much qualitative and empirical research across disciplines relating to the concept of implicit bias-the attitudes or stereotypes that affect our understanding, actions, and decisions in an unconscious, rather than conscious, manner. ${ }^{96}$ According to one articulation, "the science of implicit cognition

93. $I d$.

94. See id. at 5-6.

95. Id. at 4.

96. See Anthony G. Greenwald \& Linda Hamilton Krieger, Implicit Bias: Scientific Foundations, 94 CALIF. L. Rev. 945, 945 (2006) ("The assumption that human behavior is largely under conscious control has taken a theoretical battering in recent years."); Christine Jolls \& Cass R. Sunstein, The Law of Implicit Bias, 94 CALIF. L. REv. 969, 978 (2006) ("A central problem in today's world . . is that many people act on the basis of implicit bias.”); Jerry Kang \& Kristin Lane, Seeing Through Colorblindness: Implicit Bias and the Law, 58 UCLA L. REV. 465, 469 (2010) (explaining that "social cognitions, whether they be attitudes or stereotypes, can be either implicit or explicit"); John T. Jost et al., The Existence of Implicit Bias Is Beyond Reasonable Doubt: A Refutation of Ideological and Methodological Objections and Executive Summary of Ten Studies That No Manager Should Ignore, 29 Res. Organizational BEHAv. 39, 40 (2009) (noting that "social scientific discoveries seem to challenge long cherished personal or cultural assumptions, such as . . that . . human thought and behavior are largely under the control of individual will and consciousness"); Jules Holroyd et al., Responsibility for Implicit Bias, 12 PHIL. Compass (2017) ("Research programs in empirical psychology from the past two decades have revealed that implicit biases are pervasive. Implicit biases are typically characterized as automatic as- 
suggests that actors do not always have conscious, intentional control over the processes of social perception, impression formation, and judgment that motivate their actions." 97 Widely hailed as the key to a new diversity paradigm, implicit biases are thought to be extremely pervasive and do not always align with our declared beliefs. ${ }^{98}$

Implicit bias is often associated with biases relating to race and ethnicity but may also extend to other social categories. ${ }^{99}$ To this end, people can act on the basis of various stereotypes and prejudice without so intending. ${ }^{100}$ According to social scientist David R. Williams, "This is the frightening point: Because [implicit bias is] an automatic and unconscious process, people who engage in this unthinking discrimination are not aware of the fact that they do it." ${ }^{101}$ A specific type of implicit bias is linguistic bias-"a systematic asymmetry in word choice that reflects the social-category cognitions that are applied to [a] described group or individual[ ]." ${ }^{102}$

\section{B. Linguistic Bias}

Language "is a subtle but powerful way to examine cognition in intergroup contexts." 103 It is no longer a secret that stereotypes and social categorizations play an integral part in social interaction, perception, and judgment. ${ }^{104}$ Stereotypes are not always negative-at times they can function to simplify the complexities of our social and legal environments. ${ }^{105}$ However, in some instances the use of stereotypes can promote discrimination and prejudice when people are treated based on "generic stereotypic expectancies, rather than on available individuating information." 106 Discrimination and prejudice often emerge, in particular, from the generalized and negative associa-

sociations, of which we may not be aware, that are difficult to control and may conflict with our professed beliefs and values.").

97. Greenwald \& Krieger, supra note 96, at 946.

98. Cheryl Staats, State of the Science: Implicit Bias Review 2014, KIRwAn Inst. 17 (2014), http://kirwaninstitute.osu.edu/wp-content/uploads/2014/03/2014-implicitbias.pdf [https://perma.cc/N2TK-6ARU].

99. See, e.g., Debra Chopp, Addressing Cultural Bias in the Legal Profession, 41 N.Y.U. Rev. L. Soc. Change 364, 377 (2017).

100. Project Implicit's test is available online and widely used as one assessment of implicit bias. ProJect IMPLicit, https://implicit.harvard.edu/implicit/ [https:// perma.cc/ZXT2-CQSH].

101. Cheryl Staats, supra note 98 , at 16.

102. Camiel J. Beukeboom \& Christian Burgers, Linguistic Bias, OXford Res. ENCYCLOPEDIAS 1 (Jul. 2017) https://doi.org/10.1093/acrefore/9780190228613.013.439 [https://perma.cc/LU8P-3Y4B].

103. Quinetta M. Roberson, Bradford Bell \& Shanette C. Porter, The Language Bias: A Linguistic Approach to Understanding Intergroup Relations, 11 Res. MANAGING Grps. Teams: Diversity \& Grps. 267, 269 (2008).

104. Beukeboom \& Burgers, supra note 102 , at 1.

105. See, e.g., Gordon B. Moskowitz, Social Cognition: Understanding SElF AND OTHERs 439 (Abraham Tesser ed., 2005).

106. Beukeboom \& Burgers, supra note 102, at 1. 
tions that people hold regarding social categories like ethnicity, age, gender, and other minority groups. ${ }^{107}$ Yet social categories may also include other conventional categories such as professions and other meaningful categorizations within our culture, such as athlete, citizen, customer, or consumer.

The literature on linguistic bias reveals three types of bias: (1) labeling bias; (2) communication bias; and (3) biases inherent in formulating information about categorized individuals. Most directly relevant is the first category, labeling bias. Labeling refers to the use of a specific word or words to refer to a social category, such as the consumer label. Use of conventional category labels confirms, maintains, and reinforces the categories which are considered meaningful for categorization within a culture or subculture. These category labels have "important consequences for impression formation." 108 When a "group is linguistically labeled, it is explicitly defined and distinguished from other groups, and thereby gains in apparent reality."109

In fact, research finds that "even trivial category labels induce perceivers to accentuate perceived similarity among members within the labeled category (i.e., they are all alike) and to exaggerate the differences between categories." 110 Moreover, when "a label is imposed on an aggregate of individuals it obscures our perception of diversity between individual category members." 111 Thus, labeling can lead to the formation of stereotypes within a given category - "the more a collection of individuals is perceived as a meaningful, coherent group, the more likely perceivers will seek stereotypic characteristics that are considered to be essential to its members." 112 Once stereotypes are formed, use of the category label is enough for its users to call to mind the existing stereotype. ${ }^{113}$

Use of noun-category labels, in particular, was found to lead to more stereotype-confirming inferences than verbs did (e.g., a "consumer" (noun) versus "someone who consumes as much as possible" (verb)) ${ }^{114}$ Further, use of plural noun labels tends to have a greater stereotyping effect than does use of singular nouns (e.g., "consumers" versus "this consumer is"). ${ }^{115}$ In fact, if "negative and derogatory (metaphorical) nouns" are used to describe certain social categories,

107. Id.

108. Id. at 3.

109. $I d$.

110. Id.

111. Id. at 4 .

112. $I d$.

113. Id.

114. Sylvie Graf et al., Nouns Cut Slices: Effects of Linguistic Forms on Intergroup Bias, 43 J. Lang. Soc. Psych. 62, 77 (2013).

115. Marjorie Rhodes, Sarah-Jane Leslie \& Christina M. Tworek, Cultural Transmission of Social Essentialism, 109 Proc. NAT'L ACAD. SCIs. 13526, 13528-29 (2012). 
this can have "disastrous, negative consequences."116 For instance, one study discusses how use of the "parasite" label to refer to immigrants legitimizes discriminatory language toward them. ${ }^{117}$ One might infer from this research that the "DREAMer" label may also result in a certain stereotyping of immigrants, albeit the connotation is positive rather than negative. Category labels-like parasite, DREAMer, consumer, and citizen-may thus "call for and justify particular responses or even policies dealing with individuals from the category." 118

In summary, cultures tend to develop conventional labels for social categories, and stereotypes are often reflected in our use of these specific terms within language. ${ }^{119}$ Speakers may use one or more category labels to refer to the same social group. The choice of different category labels implies characteristics of the described individuals or groups. ${ }^{120}$ Different linguistic choices (e.g., nouns versus verbs) lead to distinct inferences regarding certain groups. ${ }^{121}$ To this end, use of noun labels rather than verb or adjective labels tends to lead to stronger inferences of "stereotype[-]consistent characteristics and behaviors" among a given category. ${ }^{122}$ Therefore, "the choice of one label over the other not only follows from but also induces recipient inferences that are in line with the social category stereotype of those using the label." ${ }^{123}$ The kinds of labels we use represent existing social category perceptions. ${ }^{124}$ Once a given category label is activated, "we tend to predominantly communicate stereotype-consistent (rather than inconsistent) information." 125 And all of this tends to be implicit—occurring largely outside of our conscious awareness.

\section{Consumer Bias}

An influential social psychology study, Cuing Consumerism, led by Galen Bodenhausen and a team of Northwestern University researchers, found that being labeled a consumer, versus a term like citizen or individual, can lead to negative, stereotype-consistent characteristics given its linguistic-biasing effect. ${ }^{126}$ These behaviors include reduced social engagement, negative affect, selfishness, and competitiveness. ${ }^{127}$ The experiment was designed in part to empirically test famed econo-

116. Beukeboom \& Burgers, supra note 102, at 6 .

117. Andreas Musolff, Metaphorical Parasites and "Parasitic" Metaphors: Semantic Exchanges Between Political and Scientific Vocabularies, 13:2 J. Language \& Pol. 218, 218-33 (2014).

118. Beukeboom \& Burgers, supra note 102, at 6-7.

119. Id. at 7.

120. $I d$.

121. $I d$.

122. $I d$.

123. Id.

124. Id. at 3.

125. $I d$. at 12 .

126. Bauer et al., supra note 27 , at 522.

127. Id. 
mist and sociologist Thorstein Veblen's theory of "conspicuous consumption." 128 Specifically, the researchers hypothesized that "activation of materialistic thinking is likely to elicit a vicious cycle in which one feels continuously dissatisfied relative to individuals who own more." 129

The experiments within the study found that framing messages in terms of a "consumer identity" can indeed "activate a consumption mindset in the audience." 130 Regardless of individual personalities, the researchers hypothesized that "in situations that activate a consumer mindset, people show the same sorts of problematic patterns in wellbeing, including negative affect and social disengagement." 131 To test this, Bodenhausen and his team conducted two different experiments relating to labeling bias as to the term consumer.

In the first experiment, the researchers framed a computer task "as a study of "consumer reactions"" versus a "control condition[ of] "citizen reactions[.]" 132 Through this study, they "examined whether participants' automatic evaluative reactions to terms signaling materialistic values (i.e., words related to social status, success, wealth, etc.) would become more positive after exposure to a consumer cue." 133 The study described the procedure, in part, as follows:

Participants completed the experiment at individual computer stations. The experimental manipulation was conveyed by the initial task instructions, to which participants were randomly assigned. In the consumer-cue condition, the heading for the instructions was "Consumer Reaction Study," and the stated purpose of the study was to see "how well consumers can rapidly categorize objects." At the end of the instructions, participants were asked to confirm their eligibility for the study by checking a box indicating that they were "an American consumer." In the control condition, everything was the same except that the word "consumer" was always replaced with "citizen."

After being oriented to the task in one of these ways, participants were asked to complete the EMA [(Evaluative Movement Assessment)] procedure. They were first given a list of the task stimuli, which fell into three focal categories: positive emotion words (e.g., happy), negative emotion words (e.g., sad), and non-emotion words. Although not described as such to the participants, the words in the latter category reflected a variety of social values. Of primary interest were the words reflecting self-enhancement values (i.e., wealth,

128. See generally Thorstein Veblen, The Theory of the Leisure Class (1899); see also Jeremy N. Scheff, Veblen Brands, 96 Minn. L. Rev. 769 (2012) (applying Veblen's theory to modern trademark law, particularly the post-sale confusion doctrine).

129. Bauer et al., supra note 27 , at 518 .

130. Id.

131. Ass'n for Psych. Sci., supra note 30.

132. Bauer et al., supra note 27 , at 518 .

133. Id. at 519. 
image, success, power, competitive). [The study] also included words relating to conservative self-restraint (i.e., moderation, discipline, obedience, frugal, humble), to self-transcendence (i.e., honest, equality, helpful), and to self-indulgence (i.e., pleasure, enjoyment, indulgence, thrill). ${ }^{134}$

Participants in the Consumer Reaction Study exhibited a stronger automatic bias toward "words reflecting materialistic values, such as wealth, image, and success, when the categorization task was framed as dealing with consumer reactions, compared with when the same task was framed as dealing with citizen reactions." ${ }^{35}$ The researchers thus concluded that "situationally activated consumer cues can orient automatic response tendencies, bringing them into greater alignment with materialistic concerns."136

Baudenhausen conducted a second experiment involving the scenario of a hypothetical water crisis. This scenario likewise concerned the term consumer, except now in comparison to the term "individual."137 The procedure was as follows:

Participants were directed to an online survey that they completed on their own computers. They were asked to read and respond to a scenario involving a resource dilemma. Specifically, they read about a water crisis affecting a set of four different individuals who access the same well for their water. Respondents were asked to put themselves in the place of one of these individuals ("A"). In the consumer-framing condition, all of the references to the persons involved in the crisis used the term consumers, and the specific individuals were referred to as Consumer A, Consumer B, and so forth. In the control condition, the term individuals was used instead (e.g., Individual A, Individual B, etc.) to refer to the parties involved. The description of the crisis indicated that, because of a drought, the local water supply was threatened, and the usual demand could not be met. Participants were then given information about past usage levels of the shared resource, which revealed that Consumer A/Individual A (i.e., the person they were role-playing) had been using more water than the others.

After reading the scenario, participants provided a number of ratings on 7 -point scales $(1=$ not at all, $7=$ very much $)$. Specifically, they rated (a) how responsible they felt for dealing with the crisis, (b) how obligated they felt to cut their water usage, (c) how much they trusted the other parties involved to use less water, (d) how much they viewed the others as partners, and (e) how much they believed that the others should use less water than they themselves did. ${ }^{138}$

134. Id. at 519-20.

135. Id. at 520.

136. Id.

137. Id. at 521-22.

138. Id. 
Here, the researchers found that, in comparison to the individual label, the consumer label "resulted in lower feelings of personal responsibility for dealing with the resource dilemma, markedly lower trust in the other parties, and a significantly lower tendency to view the others as partners in facing the dilemma[ ]." 139 Thus, the researchers concluded that consumer worked against "positive, cooperative engagement with other people." ${ }^{140}$ As Bodenhausen puts it: "Framing information in terms of its relevance to consumers (rather than e.g., citizens) . . . did not unite-it divided." ${ }^{141}$ However, if a different term-like citizen or individual-is used instead, "that subtle difference activates different psychological concerns." ${ }^{142}$

\section{Rethinking Trademark Law's Consumer Label}

Considering the research presented in Parts II and III, this Part urges those involved with trademark and advertising law-courts, lawyers, scholars, and lawmakers-to rethink our constant use of the word consumer to label the purchasing public. Many scholars have objected to trademark law's defining consumers in ways that are "biased, patronizing, sexist, or insulting, and ... too indulgent of claims of likely confusion." ${ }^{143}$ Yet few have questioned the semantic use of the term consumer itself within trademark law.

Because trademarks are psychological in nature, questions of infringement, dilution, distinctiveness, and other trademark doctrines rely almost entirely on ascertaining the mental state of the consumer. ${ }^{144}$ In this regard, trademark law treats the purchasing public as a dehumanized, objectified, and purely economic-focused entity. ${ }^{145}$

139. Id. at 522 .

140. Id.

141. $I d$.

142. Id. To this end, research suggests that English "has become a peculiarly capitalist language." See Owen Hatherley, Opinion, Be a User, Not a Consumer: How Capitalism Has Changed Our Language, Guardian (Aug. 11, 2013, 4:30 PM), https:// www.theguardian.com/commentisfree/2013/aug/11/capitalism-language-raymond-williams [https://perma.cc/R5R3-5AVU]. Researchers at the University of California Los Angeles found that over the past 200 years there has been an increasing use of acquisitive words like "self," "get," "unique," "choose," and "individual," while words like "obliged" and "give" have decreased. Id.

143. Grynberg, supra note 36, at 76; see also McCARTHY, supra note 9, at $\S 23: 92$ ("[W]hen the court wants to find no infringement, it says that the average buyer is cautious and careful and would never be confused. But if the judge thinks there is infringement, ... the average buyer is gullible and ... easily confused by the similar marks."); Gerhardt, supra note 22, at 499 ("[C]ourts should reject the patronizing view of the public that has been used as a mechanism for harming actual consumer interests.").

144. See, e.g., Mark Bartholomew, Neuromarks, 62 Minn. L. Rev. 521, 522 (2018) ("Estimates of consumer thought form the bulk of trademark doctrine.").

145. Beebe, supra note 5, at 2021-23. Like copyright doctrine embraces an "impossibly romantic" author construct, trademark doctrine employs an "impossibly utilitarian" consumer construct. Id. Trademarks are said to "exist only to the extent that consumers perceive them as designations of source." Id. 
Trademark holders, rather than the public, file lawsuits under the Lanham Act. ${ }^{146}$ In fact, the state of trademark law's treatment of consumers strikingly mirrors the materialistic concerns with the term identified in previous parts of this Article. The consumer label's stereotype of mass consumption and passivity - rather than active co-creation and engagement-may be biasing trademark law toward this mindset.

Trademark law's consumption-focused treatment of the public has several negative consequences. Among them are: (1) the overprotection of trademark rights to the exclusion of a vibrant public domain; and (2) the public's lack of standing to sue under trademark law. These problems are discussed in turn. In effect, consumers are paternalistically prevented from being confused or misled to the exclusion of a broader focus on meaningful discourse, creativity, discussion, advocacy, and expression. The consumer label might very well be partly to blame for this phenomenon, resulting in unequal power dynamics between trademark owners-who wield power under trademark law-and the public-who does not.

\section{A. The Gullible Consumer}

Consumers-the legal fiction employed by trademark law-are generally seen as susceptible fools, primarily economic beings who are easily manipulated by advertising's persuasive function. ${ }^{147}$ The consumer metaphor and stereotype manifest in trademark law's treatment of its subjects as passive, glib, helpless, and naïve. And the consumer is thus seen merely as "one who 'consumes'-one entitled at most to a negative freedom from confusion without the benefit of any positive theory that actively carves out space for her role in the trademark conversation." 148 To this end, trademark rights have been expanded and strengthened based on unproven and incorrect allegations about the ignorance and poor reasoning skills of the public. ${ }^{149}$ Several commentators have examined this condescending treatment.

146. Grynberg, supra note 36 , at 72.

147. As Beebe puts it:

To formulate a theory of the consumer as sovereign in one sense and fool in the other is to formulate a theory not just of the consumer, but of the citizen. One's theory of trademark law, it must be emphasized, is a species of one's theory of politics. And as a theory of politics, the apologists and restrictionist schools offer us in the schizoid consumer the world of each of their worlds. The political-economic subject is either confused or deluded; he either chooses on instinct but mistakenly chooses other than what his instinct instructed him to choose, or he chooses what he intended but chooses it according to external command. In either case, the subject may be said to have lost control over the ends of his actions, i.e., to have lost his sovereignty.

Beebe, supra note 5, at 2062-63.

148. Heymann, supra note 22, at 656.

149. Bartow, supra note 22, at 723 . 
In her landmark essay, Breakfast with Batman, Jessica Litman noted that in recent decades we have seen the rise of "the extraordinarily gullible consumer. Courts have been generous in interpreting the scope of confusion from which today's credulous purchasers must be protected." 150 Similarly, Laura Heymann finds that "trademark law constructs the consumer worldview in ways that minimize the relevance of consumers' own independent thinking." 151 And Graeme Austin observes that "trademark law often seems to be premised on the idea that consumers are mesmerized by brands and are incapable of very much independent thought." 152 Consumers are understood as creatures whose imaginations are frequently "burdened" by choices in the marketplace. ${ }^{153}$ Austin writes:

Furthermore, evidence of the normative construction of trademark law's consumer can be found in many strands of trademark: the idea that "having to think harder" is a burden; the rationalization of post-sale confusion on the basis that consumers need to be protected in their investment in prestigious brands; the idea that "harm" occurs when shoppers' interest is piqued by the wrong brand, even if that confusion is dissipated before any purchase is made; and the presumption that consumers will be confused by unlicensed promotional goods. ${ }^{154}$

Indeed, trademark cases often view consumers as fools. ${ }^{155}$ For example, in Eli Lilly \& Co. v. Natural Answers, Inc., the Seventh Circuit affirmed a likelihood of confusion between the antidepressant PROZAC and the "mood elevation" herbal remedy HERBROZAC. ${ }^{156}$ In what seems like a clear stretch, the district court wrote:

Considering all the [likelihood-of-consumer-confusion factors], the court concludes that Lilly has shown an unusually strong case on the issue of likelihood of confusion. Most important here are the unusual strength of Lilly's PROZAC mark, the strong similarity between PROZAC and HERBROZAC, and defendant's intentional selection of the HERBROZAC name precisely because of its similarity to PROZAC for the purpose of suggesting an association or affiliation between the two products. Add to this mixture the fairly

150. Jessica Litman, Breakfast with Batman: The Public Interest in the Advertising Age, 108 Yale L.J. 1717, 1722 (1999).

151. Heymann, supra note 22, at 655 (citing Graeme W. Austin, Trademarks and the Burdened Imagination, 69 BRoOK. L. Rev. 827, 832 (2004)).

152. Austin, supra note 19 , at 829.

153. $I d$.

154. Id. at 835 .

155. See Beebe, supra note 5, at 2023 ("For at least the half century since Ralph Brown's Advertising and the Public Interest, restrictionist trademark commentary has charged, often quite comically, that the consumer is not so much the sovereign as the fool, the 'Pavlovian' stooge of the advertising industry.").

156. Eli Lilly \& Co. v. Nat. Answers, Inc., 233 F.3d 456, 465-66 (7th Cir. 2000), aff'g 86 F. Supp. 2d 834 (S.D. Ind. 2000). 
close "competitive proximity" of the two products, especially as pharmaceutical companies expand into the herbal and dietary supplement business, and Lilly has made a powerful showing of likelihood of success on its claim for trademark infringement. ${ }^{157}$

In Anheuser-Busch, Inc. v. Balducci Publications, the Eighth Circuit ruled that a parody ad for "Michelob Oily" infringed on AnheuserBusch's Michelob beer under the theory that consumers would, despite the unflattering nature of the use, believe that Michelob authorized or licensed the use of its mark in the parody. ${ }^{158}$ In Lois Sportswear, U.S.A., Inc. v. Levi Strauss \& Co., the Second Circuit invoked a post-sale confusion theory to stop Lois Sportswear from selling designer jeans with a back pocket stitching resembling Levi's pattern. ${ }^{159}$ The court worried that third parties seeing the purchased jeans worn in public might infer from the stitching pattern that they were Levi's jeans, despite the labels clearly indicating otherwise at the point of sale. ${ }^{160}$ And in MGM-Pathe Communications Co. v. Pink Panther Patrol, the Southern District of New York found that an LGBTQ rights group using the name "Pink Panther Patrol," despite existing worlds apart, might confuse consumers into believing that the movie studio MGM authorized using the name "Pink Panther." ${ }^{61}$ As far back as 1984, Robert Denicola expressed dismay at this increasing phenomenon:

Such presumptive idiots are apparently befuddled by nearly everything, although one must wonder how prolonged a search would be required to identify a flesh and blood consumer who actually believes that the General Election Corporation would manufacture or sponsor T-shirts on which the G.E. logo and the words "Genital Electric" appear, or who assumes that a coffee mug proclaiming "I Love E.T." is necessarily connected with Universal City Studios, Incorporated. ${ }^{162}$

Courts likewise speak down to the consumer in a condescending tone. As one source puts it, "[t]he basis for claiming private ownership over a real word is often a condescending attitude toward the consumer. This kind of condescension is the source of many expansive

157. Eli Lilly \& Co. v. Nat. Answers, Inc., 86 F. Supp. 2d 834, 846 (S.D. Ind. 2000).

158. Anheuser-Busch, Inc. v. Balducci Publ'ns, 28 F.3d 769, 777 (8th Cir. 1994). Even though Anheuser-Busch would never actually sell a product called Michelob Oily.

159. Lois Sportswear, U.S.A., Inc. v. Levi Strauss \& Co., 799 F.2d 867, 875 (2d Cir. 1986).

160. Id. at 876.

161. MGM-Pathe Commc'ns Co. v. Pink Panther Patrol, 774 F. Supp. 869, 875 (S.D.N.Y. 1991).

162. Denicola, supra note 22, at 608-09 (citing Gen. Elec. Co. v. Alumpa Coal Co., 205 U.S.P.Q. (BNA) 1036 (D. Mass. 1979); Universal City Studios, Inc. v. Kamar Indus., Inc., 217 U.S.P.Q. (BNA) 1162 (S.D. Tex. 1982)). 
claims to trade[]mark rights." 163 For example, the Seventh Circuit wrote in August Storck K.G. v. Nabisco, Inc.: "Many consumers are ignorant or inattentive, so some are bound to misunderstand no matter how careful a producer is." 164 Other courts note that trademark law is designed to protect the "gullible and ignorant"165 or "ignorant, unthinking, or credulous"166 consumer. Courts have remarked that when consuming, consumers "do not stop to analyze, but are governed by appearances and general impressions."167 The mind of the consumer, when shopping, has been described by one court as "not unlike that of hypnosis." 168

To make matters worse, this condescension is particularly pronounced when consumers are women or minorities or are from a nonaffluent socioeconomic group. Ann Bartow found that the tendency of jurists in trademark decisions to engage in demeaning conceptions of consumers-as "unsophisticated, easily confused rubes"169-is especially prevalent in case law where goods and services are designed for, marketed to, and purchased by women and minorities. ${ }^{170}$ Based on Bartow's extensive survey of the case law, she finds that consumer confusion is more likely to be found when the underlying goods or services "are female oriented in some manner" as compared to where they are "more male identified." 171 Thus, judges tend to "reserve their lowest expectations for presumptively confused female consumers."172

For example, in Ithaca Industries, Inc. v. Essence Communications, Inc., the Western District of North Carolina found a likelihood of consumer confusion in the marketplace between "Sheer Essence" pantyhose and "Essence" magazine, given that both products were marketed to black women. ${ }^{173}$ And in Schieffelin \& Co. v. The Jack Co. of Boca, the Southern District of New York remarked, while not em-

163. Tom Moore \& Bruce Lehman, Debate: Striking a Balance in Trade Mark Protection, MANAGING IP 25, 26 (2004).

164. August Storck K.G. v. Nabisco, Inc., 59 F.3d 616, 618 (7th Cir. 1995).

165. See Fotomat Corp. v. Cochran, 437 F. Supp. 1231, 1244 (D. Kan. 1977) ("The law protects the gullible and ignorant consumer as much as the careful and intelligent consumer."); see also E. \& J. Gallo Winery v. Consorzio del Gallo Nero, 782 F. Supp. 457, 465 (N.D. Cal. 1991) (stating the same).

166. Florence Mfg. Co. v. J.C. Dowd \& Co., 178 F. 73, 75 (2d Cir. 1910).

167. Id.

168. Meat Indus. Suppliers, Inc. v. Kroger Co., 130 U.S.P.Q. 434, 439 (N.D. Ill. 1961) (citation omitted).

169. Bartow, supra note 22, at 723.

170. Id. at 776-77.

171. Id. at 778 .

172. Id. at 789 .

173. Ithaca Indus., Inc. v. Essence Commc'ns, Inc., 706 F. Supp. 1195, 1210 (W.D.N.C. 1986); see also Nailtiques Cosmetic Corp. v. Salon Scis., Corp., 41 U.S.P.Q.2d 1995, 1998 (S.D. Fla. 1997) (finding that consumers were unable to distinguish between "Nailtiques" and "Pro-Techniques" marks on bottles of nail polish); Am. Home Prods. Corp. v. Chattem, Inc., No. 84 Civ. 3671 (RLC), 1986 WL 6167, at *5 (S.D.N.Y. May 27, 1986) (finding that consumers could not distinguish between the over-the-counter drug "Premesyn PMS," for relief of premenstrual syndrome symp- 
ploying the term consumer specifically, that "some of the prospective purchasers of DOM PERIGNON are from low-income groups, and are therefore less sophisticated shoppers than wealthier purchasers . ..." ${ }^{174}$ In this way, in evaluating as one factor the sophistication of the consumer, trademark law's likelihood-of-confusion test actually encourages trademark owners to question their purchasers' intelligence. It is ironic that the plaintiff in a trademark action "is often placed in the awkward position of arguing that its customers are ignorant and its goods commonplace, while the defendant begs to differ." 175

In effect, trademark law has expanded its likelihood-of-confusion analysis under a thinly veiled guise of consumer protection. ${ }^{176}$ Courts find too many trademark uses to be infringing, even where the confusion has not been shown to be harmful-and might even be helpful to consumers in encouraging a degree of reflection prior to purchasing goods or services. But not all confusion is harmful confusion in that it often does not interfere with the public's decision-making ability in the marketplace. ${ }^{177}$ Yet, considering the "low opinions of consumers that some judges hold," persuading them that there is a likelihood of confusion can be "fairly easy to accomplish." 178

Perhaps, though, rather than "coddling consumers," 179 judges could shift their view of the public so as to presume it is reasonable and sophisticated. This would create a greater burden for plaintiffs in cases of alleged infringement, thereby curbing the current overprotection of trademark law. Bartow writes regarding this point:

Unless a mark holder offers persuasive evidence to the contrary, courts must reject the specter of the gullible, harried, ignorant, and stupid consumer as a standard by which to measure likelihood of confusion. Instead, courts should consistently embrace something along the lines of the "reasonably careful purchaser," with the approximate purchasing sophistication of the judge deciding the issue- a creature far more intelligent and discerning than the consumers currently manifest in trademark jurisprudence. ${ }^{180}$

Not referring to the public as consumers might provide a starting point in this regard.

toms, and prescription drug "Premarin," for use in connection with estrogen replacement therapy to treat menopause).

174. Schieffelin \& Co. v. Jack Co. of Boca, 850 F. Supp. 232, 250 (S.D.N.Y. 1994).

175. Beebe, supra note 5, at 2035.

176. Litman, supra note 150 , at 1722 .

177. Tushnet, supra note 10, at 929; Mark P. McKenna, Testing Modern Trademark Law's Theory of Harm, 95 IowA L. Rev. 63, 117 (2009).

178. Bartow, supra note 22, at 764 .

179. Id. at 817.

180. Id. 


\section{B. The Silent Consumer}

In addition to being treated as glib, the public has no cause of action available to it under trademark law. As Michael Grynberg puts it:

Trademark litigation's structure drives the expansion of trademark rights, notwithstanding consumer interests, in a variety of ways. On the most basic level, trademark holders file the lawsuits. Whatever the centrality of consumer protection to trademark law, vindicating this interest is out of consumer hands. The self-interest of the plaintiff trademark holders determines the range of cases pursued. ${ }^{181}$

While the plain language of the Lanham Act does not restrict standing to mark holders or competitors, the Supreme Court held, in Lexmark International, Inc. v. Static Control Components, Inc., that consumers do not have standing to sue for false advertising under the Act. ${ }^{182}$ Intellectual property lawyers and scholars also presumed that Lexmark prevents the public from suing under the Lanham Act's other provisions-such as for trademark infringement or dilution.

Considering this lack of consumer standing, the public has no active involvement in shaping trademark law's doctrine beyond its role as a manipulatable legal fiction. In other words, the consumer construct operates as a mere pretextual mechanism for measuring harm to mark owners. That is, to the extent that consumers are confused and thereby diverted to other brands, trademark holders suffer damages in the form of "a likelihood of consumer confusion." 183 As the Seventh Circuit wrote, "trademark laws exist not to 'protect' trademarks, but ... to protect the consuming public from confusion, concomitantly protecting the trademark owner's right to a non-confused public." 184

This silencing of the public is inconsistent with its recent tendency toward trademark activism. ${ }^{185}$ Following the fall of Section 2(a) of the Lanham Act-prohibiting registration of scandalous and disparaging trademarks-in Matal v. Tam and Iancu v. Brunetti, there no longer exists a moral policing mechanism in U.S. trademark doctrine. ${ }^{186}$ As Sonia Katyal initially predicted: "Brands, like people, don't exist on a level playing field. The real winners here are the Dan Snyders of the world. The rest of us are probably FUCT." 187

181. Grynberg, supra note 36 , at 72 .

182. Lexmark Int'l, Inc. v. Static Control Components, Inc., 572 U.S. 118, 131-32 (2014).

183. Id. at 543.

184. James Burrough Ltd. v. Sign of Beefeater, Inc., 540 F.2d 266, 276 (7th Cir. 1976) (emphasis added).

185. Jake MacKay, Racist Trademarks and Consumer Activism: How the Market Takes Care of Business, 42 L. \& Psych. Rev. 131, 144 (2018) ("Consumer activism may be the key. ... As a consumer in a capitalist society, you have the freedom to choose which products you buy, and from which companies.").

186. Sonia K. Katyal, Brands Behaving Badly, 109 Trademark Rep. 819, 829, 831 (2019).

187. Id. at 832 . 
Yet since then, the task of moral policing in trademark law has shifted entirely to members of the activist public, who have succeeded in "canceling" several widely offensive and objectionable trademarks. It is consumers - rather, citizens-who now serve as the watchful eye, and to successful results. Indeed, racist and demeaning marks-such as Aunt Jemima, Uncle Ben's, Mrs. Butterworth's, and even the Washington Redskins ${ }^{188}$ - have been removed from the marketplace in the wake of public opinion shifts following Black Lives Matter protests stemming from the brutal killing of George Floyd by Minnesota police officers. ${ }^{189}$ While companies themselves have willingly agreed to pursue alternate trademarks, they are doing so entirely as a result of activism-protests, boycotts, and backlash-on the part of the public.

Consider that in a 2018 New York Times op-ed, renowned feminist scholar Catharine MacKinnon, who pioneered the sexual harassment cause of action, remarked that "the \#MeToo movement is accomplishing what sexual harassment law to date has not." ${ }^{190}$ Here too we see the cancellation of racist and demeaning trademarks by way of public movement, not law. This illustrates the public's active, rather than passive, role in shaping trademark law's moral and economic landscape. ${ }^{191}$

More broadly, trademark law increasingly touches on aspects of social discourse and cultural creativity. Today the public uses trademarks for much more than commerce; we use trade symbols for selfexpression, value affirmation, social connection, and information

188. See Dan Cancian, Washington Redskins Name Change Will See More Investors Challenge 'Offensive' Teams, NewsweEk (July 20, 2020, 11:54 AM), https:// www.newsweek.com/washington-redskins-name-change-other-teams-1519025 [https:// perma.cc/QWL6-JMB6]. The Washington Redskins federal marks had been cancelled in Blackhorse v. Pro-Football, Inc., 111 U.S.P.Q.2d (BNA) 1080 (T.T.A.B. 2014), but were reinstated once the Supreme Court, in Matal v. Tam, 137 S. Ct. 1744, 1751 (2017), found that the Lanham Act's "disparagement" clause discriminated under the First Amendment. For a sampling of the legal literature discussing the Washington Redskins trademark saga, see Sonia Katyal, Trademark Intersectionality, 57 UCLA L. Rev. 1601 (2010); Doori Song, Comment, Blackhorse's Last Stand?: The First Amendment Battle Against the Washington "Redskins" Trademark After Matal v. Tam, 19 Wake Forest J. Bus. \& Intell. Prop. L. 173 (2019); and Victoria Phillips, Beyond Trademark: The Washington Redskins Case and the Search for Dignity, 92 CHI.-Kent L. REv. 1061, 1086 (2018) (arguing that the Washington Redskins trademark is a "dignity taking"). Cf. Dustin Marlan, Trademark Takings: Trademarks as Constitutional Property Under the Fifth Amendment Takings Clause, 15 U. PA. J. Const. L. 1581 (2013).

189. Angela R. Riley \& Sonia K. Katyal, Opinion, Aunt Jemima Is Gone. Can We Finally End All Racist Branding?, N.Y. Times (June 19, 2020), https://www.ny times.com/2020/06/19/opinion/aunt-jemima-racist-branding.html [https://perma.cc/ FE77-XG92].

190. Catharine A. MacKinnon, Opinion, \#MeToo Has Done What the Law Could Not, N.Y. Times (Feb. 4, 2018), https://www.nytimes.com/2018/02/04/opinion/metoolaw-legal-system.html [https://perma.cc/5ACJ-9T5V].

191. See MacKay, supra note 185. 
searches. ${ }^{192}$ Marks often have a social, legal, political, and cultural impact. ${ }^{193}$ For instance, the recent Supreme Court case Matal v. Tam involved the registrability of the mark "Slants" by an Asian-American rock band of the same name. ${ }^{194}$ The Slants mark identifies not just a $\mathrm{b}(\mathrm{r})$ and, but also creative expression involving social justice, power dynamics, and human identity. ${ }^{195}$ And in Iancu v. Brunetti, the apparel mark FUCT represents a nihilistic statement from beyond the commercial veil. ${ }^{196}$

Some even argue that consumers-rather, prosumers ${ }^{197}$ - "are as involved in the production of meaning, attention, and consequent value as the marketing departments of firms." 198 To the extent that brands do not consider the optics of their marks and advertising, especially in an age of social media, their sales and reputations may suffer at the hands of an increasingly empowered public. ${ }^{199}$ Yet despite this tendency toward trademark activism, members of the general public are still labeled as mere consumers and lack standing under the Lanham Act.

One rationale alleged for limiting a cause of action to markholders or competitors is that they are thought to be in a better position to evaluate issues of false advertising, infringement, or dilution than the public is. But this argument appears outdated as the public is becoming ever more actively engaged with trade symbols. As Deborah Gerhardt points out:

An entrepreneur may post a competitor's mark on its [website] to make a legitimate product comparison. Consumer safety advocates use marks to provide information about branded goods and services. Consumers use brands to find products and connect to communities with similar interests. Search engines make it possible to use brands as search terms to find information on the Internet.

192. See generally Jessica Kiser, Brandright, 70 ARK. L. Rev. 489, 493 (2017). Kiser proposes that the public be given brandrights-use rights (not merely defenses) granted to individuals to "comment on, criticize, or contribute to a specific brand . . . . Id. at 501. This would allow the public to utilize trademarks in ways reflective of the time, energy, and creativity they invest in brands, thus assisting in a reciprocal manner in creating brand goodwill. Id.

193. Chon, supra note 34, at 938.

194. Matal v. Tam, 137 S. Ct. 1744, 1751 (2017).

195. Kiser, supra note 192, at 493.

196. Iancu v. Brunetti, 139 S. Ct. 2294, 2298 (2019).

197. George Ritzer \& Nathan Jurgenson, Production, Consumption, Prosumption: The Nature of Capitalism in the Age of the Digital "Prosumer", 10 J. Consumer CulTURE 13, 14 (2010) (defining "prosumer" as a short term for "production by consumers").

198. Chon, supra note 34, at 948.

199. See, e.g., Christopher A. Jensen, Business Litigation and the "Cancel Culture", JenSEn Litig. Firm PLLC (Nov. 14, 2019), https://www.jensenlawmn.com/cancel-culture-business-litigation [https://perma.cc/ZA5L-5AFX] ("In the age of the 'Cancel Culture', companies ... must consider the optics of their legal actions. If not, they may alienate customers ...."). 
Trademark owners are not the only ones who use marks for commercial and expressive purposes. ${ }^{200}$

Thus, to the extent that the public is confused regarding a trademark that it identifies with, or believes a mark to be nondistinctive, perhaps the public should have a cause of action available to it just like trademark owners do. Indeed, if we are going to insist that consumer protection is paramount to trademark law, then those it allegedly protects should be participating members of the discourse.

Granting a trademark cause of action to the purchasing public may sound controversial and even farfetched. However, standing was, in fact, recently granted to a member of the public to oppose a trademark. In Curtin v. United Trademark Holdings, Inc. ${ }^{201}$ Professor Rebecca Curtin ${ }^{202}$ established standing at the Trademark Trial and Appeal Board ("TTAB") to challenge the distinctiveness of the mark "Rapunzel" for children's dolls. Curtin argued that Rapunzel is generic and thus lacks the distinctiveness necessary to function as a trademark for dolls. ${ }^{203}$

"No company should ever be able to be the only company that can call their doll Rapunzel, because Rapunzel is already in the public domain," believes Curtin, "Rapunzel already belongs to everyone."204 Curtin was granted standing based on her argument that, as the mother of a young child, she was "a consumer of dolls." ${ }^{205}$ According to the TTAB:

[Curtin] alleges that she is a consumer of dolls and toy figures of fairytale characters, including "Rapunzel," that she has purchased and continues to purchase said goods, and that registration of the applied-for mark by Applicant would constrain the marketplace of such goods sold under the name "Rapunzel," raise prices of "Rapunzel" dolls and toy figures, and deny consumers, such as herself, the ability to purchase "Rapunzel" dolls offered by other manufacturers. In view thereof, the Board finds that Opposer has sufficiently alleged that she has a direct and personal stake in the

200. Gerhardt, supra note 22, at 436.

201. Applicant's Reply Brief in Support of Motion to Dismiss Amended Complaint, Curtin v. United Trademark Holdings, Inc., No. 91241083, 2018 WL 4183136, at 9 (T.T.A.B. Aug. 31, 2018) [hereinafter Curtin's Reply Brief].

202. Curtin is being represented by Suffolk Law's Intellectual Property \& Entrepreneurship Clinic, led by clinic director Loletta Darden. See Julia Huston, Law Students Seek to "Free Rapunzel from the Trademark Tower" by Opposing RAPUNZEL as a Trademark for Dolls, TrAdEMARK \& Copyright L. Blog (Feb. 4, 2019), https:// www.trademarkandcopyrightlawblog.com/2019/02/law-students-seek-to-freerapunzel-from-the-trademark-tower-by-opposing-rapunzel-as-a-trademark-for-dolls/ [https://perma.cc/G43M-CVV3].

203. Curtin's Reply Brief, supra note 201, at 12-14.

204. Karen Katz, Loletta Darden \& Rebecca Curtin, Rescuing Rapunzel: Suffolk Law Professors and Students Work to Keep Fairy Tale Princess in the Public Domain, IP WATchDog (June 16, 2018), https://www.ipwatchdog.com/2018/06/16/rescuingrapunzel-fairy-tale-princess-public-domain/id=98218/ [https://perma.cc/8UFU-SHSH].

205. Id. 
outcome of the proceeding and that her belief of damage has a reasonable basis in fact. ${ }^{206}$

While a step in the right direction, the inquiry should not depend on whether Curtin is a "consumer of dolls." 207 Her gender and parental status likewise should not be a relevant consideration. Instead of analyzing the issue in "market gibberish," 208 as the TTAB does, it should be enough that Curtin is a citizen concerned that a corporation is seeking to remove from the public domain an archetypal eighteenthcentury fairytale character. ${ }^{209}$

Some might respond that allowing the public standing to challenge trademarks would open the floodgates to thousands of consumer lawsuits. ${ }^{210}$ "Curtin standing" should provide a sound litmus test-as to opposition and cancellation proceedings at the TTAB - for whether or not that is true. The enormous time and cost of litigation should be enough to dissuade the vast majority of citizens from challenging marks without a serious financial incentive to do so. ${ }^{211}$ Instead of creating docket congestion, these sorts of social justice-oriented challenges to trademark property rights generated by Curtin standing could represent a welcome addition to what otherwise constitutes a commercially obsessed intellectual property regime.

206. Curtin v. United Trademark Holdings, Inc., No. 91241083 (T.T.A.B. Dec. 28 , 2018) (TTABVUE), https://ttabvue.uspto.gov/ttabvue/ttabvue-91241083-OPP-12.pdf [https://perma.cc/WT7Z-JLNZ]. The substantive matter remains ongoing. For updates, see the case docket at Trademark Trial and Appeal Board Inquiry System, U.S. Patent \& Trademark OfF. (May 9, 2018), https://ttabvue.uspto.gov/ttabvue/v? pno $=91241083 \&$ pty $=$ OPP [https://perma.cc/F3TS-LU24].

207. Curtin, No. 91241083.

208. See Andrew Gilden, Copyright's Market Gibberish, 94 Wash L. REv. 1019, 1019 (2019) (explaining that if plaintiffs can plausibly tell a story of market harm, courts will often respond by manipulating economic rhetoric to provide the desired outcomes that have little to do with economic rights, but when courts engage in market gibberish they then obscure emotional and cultural interests in addition to economic ones).

209. See generally Rebecca Curtin, Zombie Cinderella and the Undead Public Domain, 85 TENN. L. Rev. 961, 962 (2018).

210. Paul Reidl, Comment to Ordinary Consumer Has Standing to Oppose RAPUNZEL for Dolls, Says TTAB, Blogger: TTABlog (Dec. 31, 2018, 8:47 AM), https://www.blogger.com/comment.g?blogID=9072179\&postID=56231173142036620

$77 \&$ bpli=1\&pli=1 [https://perma.cc/AN99-VACV] ("This is not good for trademark owners or the TTAB [sic] The floodgates are now open.").

211. Adam W. Sikich \& Alex Houstoun, You Don't Have to Scale a High Tower to Oppose a Trademark, DunNer LAW (Feb. 11, 2019) http://dunnerlaw.com/you-donthave-to-scale-a-high-tower-to-oppose-a-trademark/ [https://perma.cc/A7CW-RSD8] ("The Board's opinion strongly suggests that it maintains a very liberal view on what a party must do to establish standing in trademark opposition or cancellation proceedings. As a result, the Board is likely to see an uptick in these proceedings, given its broad interpretation and application of the standing requirement. The cost of these proceedings, however, may balance things out."). 


\section{The Trademark Citizen}

Bartow concludes her seminal trademark law article, Likelihood of Confusion, by stating, "all consumers should be considered classless and genderless." 212 But perhaps-as a further social justice matterthey shouldn't be considered consumers at all. Indeed, consumer is "an epithet because it disrespectfully reduces the marvelous complexity of every human being to merely a cog in the economic machine." ${ }^{13}$ If consumer is so problematic, though, then what should replace it?

The trademark regime needs an alternative word that would serve a similar denotative function but with less adverse connotations. Possibilities include "customer," "buyer," "purchaser," "participant," "person," "individual," "human," or "citizen." As a preliminary proposal, trademark law might refer to its subjects as citizens rather than as consumers-"Citizens are actively engaged in the shaping of society and the making of history; consumers simply choose between the products on display." 214 To this point, originalists may be persuaded that the trademark regime is granted its federal power through the Constitution's Commerce Clause. The Commerce Clause is "designed to govern the commerce wholly between citizens," not consumers. ${ }^{215}$ Others may need further convincing.

While citizenship is quite a loaded word in our current immigration climate, the concept of a citizen might nevertheless best express the needed push toward autonomy and respect for the public discussed at length herein. Cass Sunstein notes that "what we think and what we want often depends on the social role in which we find ourselves, and the role of the citizen is quite different from that of the consumer."216 Citizens do not act or think like consumers. ${ }^{217}$ Unlike consumers, citizens "might aspire to a communication system of a particular kindone that promotes democratic goals, and they might try to promote

212. Bartow, supra note 22 , at 817.

213. Moore, supra note 65.

214. Justin Lewis, SAnna Inthorn \& Karin Wahl-Jorgensen, Citizens or Consumers: What the Media Tells Us About Political Participation 5-6 (2005).

215. In re Trade-Mark Cases, 100 U.S. 82, 96-97 (1879) ("When, therefore, Congress undertakes to enact a law, which can only be valid as a regulation of commerce, it is reasonable to expect to find on the face of the law, or from its essential nature, that it is a regulation of commerce with foreign nations, or among the several States, or with the Indian tribes. If not so limited, it is in excess of the power of Congress. If its main purpose be to establish a regulation applicable to all trade, to commerce at all points, especially if it be apparent that it is designed to govern the commerce wholly between citizens of the same State, it is obviously the exercise of a power not confided to Congress.").

216. Cass R. Sunstein, \#Republic: Divided Democracy in the Age of Social Media 167 (2017).

217. Id. 
that aspiration through law." ${ }^{18}$ Citizens "take responsibility for the collective good" while consumers "just use stuff up." ${ }^{219}$ Citizens are active - they "don't passively receive a product or service; they build that product themselves, together." Citizens "argue, they deliberate, they deconstruct, and they create." ${ }^{220}$ In this way, citizens and consumers embody entirely distinct practices, relationships, and principles. ${ }^{221}$ Perhaps "if we saw ourselves as citizens, then that is what we might become." 222

Issues such as the need for a vibrant semiotic public domain, and the degree of active involvement that the public has in trademark law versus the scope of protection of trademarks, are better captured through using citizen. Margaret Chon, for instance, writes that "[e]mploying the vocabulary of citizenship suggests if not demands politically meaningful participation in a community, albeit one dominated by an ethos of market-based consumption." ${ }^{23}$ Indeed, the role of the active citizen, rather than the passive consumer, emphasizes trust, allegiance, loyalty, and relationships as key components of trade symbolism in a complex system of late capitalism. ${ }^{224}$

From a community development lens, John McKnight and Peter Block urge a shift in our thinking toward being "producers of our own future" rather than "purchasers of what others have in mind for us." 225 To this end, McKnight and Block define the distinction between consumer and citizen:

A citizen is one who is a participant in a democracy, regardless of their legal status. It is one who chooses to create the life, the neighborhood, the world from their own gifts and the gifts of others .... A consumer is one who has surrendered to others the power to provide what is essential for a full and satisfied life. ${ }^{226}$

According to writer and academic Jathan Sadowski, "next time someone is going on about consumer protections or what's good for consumers, you should ask why not be concerned about citizen protections or what's good for citizens. And see what new meanings, consequences, and possibilities that switch reveals."227 Abandoning consumer in favor of citizen could result in a potential "paradigm shift

218. Id. at 168 .

219. Deresiewicz, supra note 68.

220. Ned Resnikoff, In a Democracy, Citizens Are Not 'Customers' of the State, MSNBC (Sept. 13, 2013, 8:47 AM), http://www.msnbc.com/the-ed-show/democracycitizens-are-not-customers [https://perma.cc/EG3V-59DZ].

221. Sunstein, supra note 216, at 167-68.

222. Deresiewicz, supra note 68.

223. Chon, supra note 35, at 943.

224. Id.

225. John McKnight \& Peter Block, The Abundant Community: Awakening the Power of Families and Neighborhoods 26 (1st ed. 2010).

226. Id. at 7.

227. Sadowski, supra note 70. 
in democratic expectations." 228 And Jon Alexander of the New Citizenship Project writes amidst the COVID-19 pandemic:

[W]e are now living through another moment of collapse and rebirth: a shift from Consumer to Citizen. Now, the right thing for us to do is to get involved, to step into our own power to shape the world for the better, and to open up opportunities to do so for others. The flaws of the Consumer story have been badly exposed by the financial crisis and the climate emergency, and the digital era has created new spaces for participation that we can use to replace it with the Citizen story. ${ }^{229}$

We certainly see such a shift as to the public's involvement with regard to trademark and advertising matters. How realistic is such a semantic change, though, from consumer to citizen in the context of trademark law? On one hand, consumer has been around for so long and is entrenched in both society and trademark doctrine. It goes without debate, however, that many widely accepted terms and symbols that were once used to label members of various social categories are completely unacceptable today. And legal doctrine follows suit with changes in language. For example, in agency law, the Restatement Third of Employment Law has changed prior reference from a master-servant relationship to an employer-employee relationship, and many courts and commentators have followed suit. 230 Thus, the change from the derogatory consumer to a more respectful word such as citizen might be viewed not just as an academic exercise, but a realistic possibility into the future. Until that happens, we might choose to be more mindful of our use of consumer, even as we necessarily continue to use it.

\section{Conclusion}

Trademark law purports to act for the protection of consumers. However, under the transparently pretextual motive of eliminating

228. Charles D. Hayes, Citizen vs. Consumer: The Perils of Deflationary Democracy, FRUGALFun, https://www.frugalfun.com/citizen-vs-consumer.html [https:// perma.cc/8Z8G-AW4W].

229. Jon Alexander, Subject, Consumer, or Citizen: Three Post-Covid Futures, MEdium: New Citizenship Project (Apr. 17, 2020), https://medium.com/new-citizen ship-project/subject-consumer-or-citizen-three-post-covid-futures-8c3cc469a984 [https://perma.cc/49GM-QMDG].

230. See, e.g., Restatement of the Law Third Employment Law, Introductory Note (Ам. LaW Inst., Tentative Draft No. 2, 2009), http://laborlawgroup.org/wp-content/uploads/2015/03/TentativeDraftNo2.pdf [https://perma.cc/KCR3-VH7G] ("This [Third] Restatement generally uses the terms 'employer' and 'employee,' rather than the terms 'master' and 'servant' used in the Restatement Second of Agency (1958). This reflects ... a change in the common usage and the terminology of modern decisions - one more appropriate in a society where most individuals provide services for entities, commonly business enterprises, rather than for individuals and their families."); see also Evelyn Atkinson, Out of the Household: Master-Servant Relations and Employer Liability Law, 25 YALe J.L. \& Human. 205, 207-18 (2013). 
confusion, trademark law dehumanizes the public and prevents it from playing a meaningful role in legal discourse. This Article has suggested that the derogatory word consumer is part of the problem. Through its use of the term consumer, trademark law rhetorically treats the public as an object-as that which consumes. Indeed, consumer is an epithet, and its use results in economic injustice. We might choose, then, to phase out the use of consumer and replace it with a more appropriate term, like citizen. Alternatively, if we choose to keep using consumer for now, we should at least pause for a split second each time we do to consciously consider its potential biasing effects. 